\title{
Research Productivity of Government Aided Technical Education Institutions of Tamilnadu: A Scientometric Dimension
}

\author{
J Arumugam \\ \{jacs1986tvl@gmail.com \} \\ Librarian, PSG College of Technology, Coimbatore ${ }^{1}$, India.
}

\begin{abstract}
Scientometric dimensions have been applied to present a qualitative and quantitative analysis of publications of government aided technical education institutions of Tamilnadu. Data for the study have been collected from Scopus database for the period of 2000-2019. This paper highlights the scientific parameters such as year wise growth pattern, Authorship pattern, most prolific authors with impactful sources, institution affiliations, collaborative countries, citation at national and international level. This paper also analyzes the highly cited papers of the authors and institutional source impact. There is an increasing trend in the publications for the last ten years since the government has come up with various initiates of measuring the research productivity and its impact in the education and scientific environment..
\end{abstract}

Keywords: Research Productivity, Technical Institutions, Coimbatore Institute of Technology, PSG College of Technology, Thiagarajar College of Engineering, Scientometrics.

\section{Introduction}

Building research capacity is a common aim at an institutional level, as well as at national and international levels (Wootton, 2013). In the academic and industry settings, researchers are highly encouraged to engage in scientific research and publish study results in a timely manner using the best possible platform (Agarwal, et. al., 2016). Every institution strives to build its research capacity by all means financial, motivational, non-financial, morally so as to prove its worthiness in the current working field. The institutions wish to measure the research output or research impact of its employees. Some measure the research output by taking publication count into account while others use some indices and metrics to measure the impact of the research. Both these methods are used to assess the research performance of individual researchers or groups of researchers. Research productivity, or just productivity, refers to the amount and quality of scholarly output collectively produced by a group of researchers / institutions (Rawls, 2018). It is a total number of research publications of faculty members working in education institutions. It may be individual research productivity, departmental research productivity, institutional research productivity or a county's productivity. 


\section{Aim And Objectives Of The Study}

The present study was conducted to examine the research productivity of the faculty members of Government aided Technical higher education institutions of Tamilnadu for the period of 2000-2019.

* To examine the evolution and growth metrics of research output of selected Government aided technical HEIs in Tamilnadu

* To explore author-metrics of research output of selected Government aided technical HEIs in Tamilnadu

* To explore the geo-metrics of research output of selected Government aided technical HEIs in Tamilnadu

* To explore the source and institutional metrics of research output of selected Government aided technical HEIs in Tamilnadu

\section{Literature Review}

Pradhan and Ramesh (2017) performed a scientometric evaluation of engineering research at Indian Institutes of Technology Madras and Bombay during 2006-2015. The data for the study was downloaded from Scopus database. The findings of this study revealed that the researchers from IITM published 5378 papers and the researchers from IITB published 4430 papers on various aspects of engineering sciences in different type of document sources. The scientists of IITM published their papers in 771 journals published from 31 countries including India and the scientists of IITB published their papers in 593 journal titles published from 29 different countries including India. It indicates that about $33.48 \%$ papers by the scientists of IITM and $39.25 \%$ papers by IITB were published in journals originating from the USA. The number of papers published in journals from UK was almost the same for both IITM and IITB. The share of papers published by the authors of two institutions in journals published from India was $6.27 \%$ and $4.42 \%$ respectively by both the institutions. More number of papers published by researchers from IITB was highly cited as compared to IITM.

Mandhirasalam (2016) applied Bibliometric and scientometric techniques to present a quantitative and qualitative analysis of the publication output of PSG College of Technology (PSGCT), Coimbatore. Data for the study have been collected from the Scopus database for the period 1971 to 2014 . Among the 2357 papers published in the span of 44 years, highest number of 319 papers was published in 2012. 2112 papers $(89.6 \%)$ were published during the last ten years i.e. from 2005 to 2014 . Journal is the most preferred channel of publication with 1633 papers. 'H' Index of PSGCT is 41. This study reveals that PSGCET has largely contributed to research in science, engineering and technology and the publication output of faculty has increased considerably during the last 10 years.

Bid (2016) dealt with the analysis of publications of Indian Institute of Technology Kharagpur (IIT Kharagpur) during 2000 to 2015 appeared in SCOPUS database. It attempts to analyze the growth and development of research activity of IIT Kharagpur as reflected in publications output. Data for a total of 18927 have been downloaded and analysed according to objectives. The study reveals that the growth of literature follows the exponential growth pattern, journal articles are the most published form of literature (74.37\%), Journal of Applied Polymer Science and Journal of Applied Physics are top journals, Jadavpur University and 
National Institute of Technology are top collaborating institutions/university with Indian Institute of Technology, Kharagpur. The highly productive subject areas are engineering and materials science, computer science, physics and astronomy. US, Germany and UK are the most favored countries for collaborations and authorship pattern analysis shows that degree of collaboration (0.95) significantly high.

\section{Need And Significance Of The Study}

To understand the technical education institutions research productivity in terms of quantity as well as the quality to promote the research and innovation in the engineering stream. Technical education institutions are analyzed for this study to improvise the scientific publications with good number of global citation.

\section{Limitations Of The Study}

The present study covers all forms of scholarly communications of the faculty members of three government aided institutions in Tamilnadu who have secured at least in Top 100 ranking are taken into consideration. Only technical HEIs are included under the purview of the study for the period of 20 years (2000-2019). The study is limited to the research productivity as indexed in Scopus database.

\section{Methodology}

The researcher has selected the Scopus database to download the required data. Since Scopus has more coverage of journals than Web of Science, the researcher has decided to download the required data i.e. research productivity of three government aided Technical higher education institutions from Scopus database for the period of 2000 to 2019.The research output of select government aided Technical HEIs includes 8423 records approximately. BIBEXCEL, Bibliometrix and Biblioshiny, VOS Viewer and SPSS Ver.23 are used for analyzing the exported data.

\section{Data Analysis And Intrepretation}

\section{Year wise Growth Distribution of Institutions}

Table 1 shows the year wise growth distribution of selected government aided technical education institutions in Tamilnadu for the period 2000-2019. 20 years of publication record for PSG College of Technology, Coimbatore, Coimbatore Institute of Technology, Coimbatore Thiagarajar College of Engineering, Madurai has been taken for this study. The below table has the calculated data for relative growth rate, Doubling time, Annual relative growth rate and annual growth rate. 


\begin{tabular}{|c|c|c|c|c|c|c|c|c|c|c|c|c|c|c|c|}
\hline Institut & \multicolumn{5}{|c|}{ PSG } & \multicolumn{5}{|c|}{ CIT } & \multicolumn{5}{|c|}{ TCE } \\
\hline Year & $\begin{array}{l}\text { No. } \\
\text { of } \\
\text { Rec } \\
\text { ord } \\
\text { s }\end{array}$ & $\begin{array}{l}\text { RG } \\
\text { R }\end{array}$ & DT & $\begin{array}{l}\mathbf{A R} \\
\mathbf{o G}\end{array}$ & $\begin{array}{l}\mathbf{A} \\
\mathbf{G} \\
\mathbf{R}\end{array}$ & $\begin{array}{l}\text { No. } \\
\text { of } \\
\text { Rec } \\
\text { ord } \\
\text { s }\end{array}$ & $\begin{array}{l}\text { RG } \\
\text { R }\end{array}$ & DT & $\begin{array}{c}\text { AR } \\
\text { oG }\end{array}$ & $\begin{array}{l}\mathbf{A} \\
\mathbf{G} \\
\mathbf{R}\end{array}$ & $\begin{array}{l}\text { No. } \\
\text { of } \\
\text { Rec } \\
\text { ord } \\
\text { s }\end{array}$ & $\begin{array}{l}\text { RG } \\
\text { R }\end{array}$ & DT & $\begin{array}{l}\text { AR } \\
\text { oG }\end{array}$ & $\begin{array}{l}\mathbf{A} \\
\mathbf{G} \\
\mathbf{R}\end{array}$ \\
\hline 2000 & 28 & - & - & - & - & 4 & - & - & - & - & 6 & - & - & - & - \\
\hline 2001 & 31 & $\begin{array}{l}0.7 \\
5\end{array}$ & 0.93 & 1.11 & $\begin{array}{l}0.1 \\
1\end{array}$ & 7 & $\begin{array}{l}1.0 \\
1\end{array}$ & $\begin{array}{l}0.6 \\
9\end{array}$ & $\begin{array}{l}1.7 \\
5\end{array}$ & $\begin{array}{l}0.7 \\
5\end{array}$ & 15 & $\begin{array}{l}1.2 \\
5\end{array}$ & $\begin{array}{l}0.5 \\
5\end{array}$ & $\begin{array}{l}2.5 \\
0\end{array}$ & $\begin{array}{l}1.5 \\
0\end{array}$ \\
\hline 2002 & 38 & $\begin{array}{l}0.5 \\
0\end{array}$ & 1.39 & 1.23 & $\begin{array}{l}0.2 \\
3\end{array}$ & 7 & $\begin{array}{l}0.4 \\
9\end{array}$ & $\begin{array}{l}1.4 \\
1\end{array}$ & $\begin{array}{l}1.0 \\
0\end{array}$ & $\begin{array}{l}0.0 \\
0\end{array}$ & 20 & $\begin{array}{l}0.6 \\
7\end{array}$ & $\begin{array}{l}1.0 \\
4\end{array}$ & $\begin{array}{l}1.3 \\
3\end{array}$ & $\begin{array}{l}0.3 \\
3\end{array}$ \\
\hline 2003 & 47 & $\begin{array}{l}0.4 \\
0\end{array}$ & 1.75 & 1.24 & $\begin{array}{l}0.2 \\
4\end{array}$ & 10 & $\begin{array}{l}0.4 \\
4\end{array}$ & $\begin{array}{l}1.5 \\
7\end{array}$ & $\begin{array}{l}1.4 \\
3\end{array}$ & $\begin{array}{l}0.4 \\
3\end{array}$ & 24 & $\begin{array}{l}0.4 \\
6\end{array}$ & $\begin{array}{l}1.5 \\
0\end{array}$ & $\begin{array}{l}1.2 \\
0\end{array}$ & $\begin{array}{l}0.2 \\
0\end{array}$ \\
\hline 2004 & 89 & $\begin{array}{l}0.4 \\
8\end{array}$ & 1.44 & 1.89 & $\begin{array}{l}0.8 \\
9\end{array}$ & 14 & $\begin{array}{l}0.4 \\
1\end{array}$ & $\begin{array}{l}1.7 \\
1\end{array}$ & $\begin{array}{l}1.4 \\
0\end{array}$ & $\begin{array}{l}0.4 \\
0\end{array}$ & 29 & $\begin{array}{l}0.3 \\
7\end{array}$ & $\begin{array}{l}1.8 \\
8\end{array}$ & $\begin{array}{l}1.2 \\
1\end{array}$ & $\begin{array}{l}0.2 \\
1\end{array}$ \\
\hline 2005 & 134 & $\begin{array}{l}0.4 \\
5\end{array}$ & 1.53 & 1.51 & $\begin{array}{l}0.5 \\
1\end{array}$ & 16 & $\begin{array}{l}0.3 \\
2\end{array}$ & $\begin{array}{l}2.1 \\
5\end{array}$ & $\begin{array}{l}1.1 \\
4\end{array}$ & $\begin{array}{l}0.1 \\
4\end{array}$ & 47 & $\begin{array}{l}0.4 \\
1\end{array}$ & $\begin{array}{l}1.7 \\
1\end{array}$ & $\begin{array}{l}1.6 \\
2\end{array}$ & $\begin{array}{l}0.6 \\
2\end{array}$ \\
\hline 2006 & 166 & $\begin{array}{l}0.3 \\
7\end{array}$ & 1.86 & 1.24 & $\begin{array}{l}0.2 \\
4\end{array}$ & 47 & $\begin{array}{l}0.5 \\
9\end{array}$ & $\begin{array}{l}1.1 \\
7\end{array}$ & $\begin{array}{l}2.9 \\
4\end{array}$ & $\begin{array}{l}1.9 \\
4\end{array}$ & 57 & $\begin{array}{l}0.3 \\
4\end{array}$ & $\begin{array}{l}2.0 \\
4\end{array}$ & $\begin{array}{l}1.2 \\
1\end{array}$ & $\begin{array}{l}0.2 \\
1\end{array}$ \\
\hline 2007 & 211 & $\begin{array}{l}0.3 \\
3\end{array}$ & 2.08 & 1.27 & $\begin{array}{l}0.2 \\
7\end{array}$ & 49 & $\begin{array}{l}0.3 \\
8\end{array}$ & $\begin{array}{l}1.8 \\
1\end{array}$ & $\begin{array}{l}1.0 \\
4\end{array}$ & $\begin{array}{l}0.0 \\
4\end{array}$ & 67 & $\begin{array}{l}0.2 \\
9\end{array}$ & $\begin{array}{l}2.3 \\
8\end{array}$ & $\begin{array}{l}1.1 \\
8\end{array}$ & $\begin{array}{l}0.1 \\
8\end{array}$ \\
\hline 2008 & 192 & $\begin{array}{l}0.2 \\
3\end{array}$ & 3.02 & 0.91 & $\begin{array}{l}0.0 \\
9\end{array}$ & 54 & $\begin{array}{l}0.3 \\
0\end{array}$ & $\begin{array}{l}2.3 \\
1\end{array}$ & $\begin{array}{l}1.1 \\
0\end{array}$ & $\begin{array}{l}0.1 \\
0\end{array}$ & 117 & $\begin{array}{l}0.3 \\
7\end{array}$ & $\begin{array}{l}1.9 \\
0\end{array}$ & $\begin{array}{l}1.7 \\
5\end{array}$ & $\begin{array}{l}0.7 \\
5\end{array}$ \\
\hline 2009 & 231 & $\begin{array}{l}0.2 \\
2\end{array}$ & 3.14 & 1.20 & $\begin{array}{l}0.2 \\
0\end{array}$ & 53 & $\begin{array}{l}0.2 \\
3\end{array}$ & $\begin{array}{l}3.0 \\
5\end{array}$ & $\begin{array}{l}0.9 \\
8\end{array}$ & $\begin{array}{l}0.0 \\
2\end{array}$ & 121 & $\begin{array}{l}0.2 \\
8\end{array}$ & $\begin{array}{l}2.5 \\
2\end{array}$ & $\begin{array}{l}1.0 \\
3\end{array}$ & $\begin{array}{l}0.0 \\
3\end{array}$ \\
\hline 2010 & 216 & $\begin{array}{l}0.1 \\
7\end{array}$ & 4.08 & 0.94 & $\begin{array}{l}0.0 \\
6\end{array}$ & 58 & $\begin{array}{l}0.2 \\
0\end{array}$ & $\begin{array}{l}3.4 \\
5\end{array}$ & $\begin{array}{l}1.0 \\
9\end{array}$ & $\begin{array}{l}0.0 \\
9\end{array}$ & 146 & $\begin{array}{l}0.2 \\
5\end{array}$ & $\begin{array}{l}2.7 \\
2\end{array}$ & $\begin{array}{l}1.2 \\
1\end{array}$ & $\begin{array}{l}0.2 \\
1\end{array}$ \\
\hline 2011 & 282 & $\begin{array}{l}0.1 \\
9\end{array}$ & 3.73 & 1.31 & $\begin{array}{l}0.3 \\
1\end{array}$ & 93 & $\begin{array}{l}0.2 \\
6\end{array}$ & $\begin{array}{l}2.7 \\
1\end{array}$ & $\begin{array}{l}1.6 \\
0\end{array}$ & $\begin{array}{l}0.6 \\
0\end{array}$ & 213 & $\begin{array}{l}0.2 \\
8\end{array}$ & $\begin{array}{l}2.4 \\
4\end{array}$ & $\begin{array}{l}1.4 \\
6\end{array}$ & $\begin{array}{l}0.4 \\
6\end{array}$ \\
\hline 2012 & 371 & $\begin{array}{l}0.2 \\
0\end{array}$ & 3.44 & 1.32 & $\begin{array}{l}0.3 \\
2\end{array}$ & 98 & $\begin{array}{l}0.2 \\
1\end{array}$ & $\begin{array}{l}3.2 \\
5\end{array}$ & $\begin{array}{l}1.0 \\
5\end{array}$ & $\begin{array}{l}0.0 \\
5\end{array}$ & 183 & $\begin{array}{l}0.1 \\
9\end{array}$ & $\begin{array}{l}3.6 \\
0\end{array}$ & $\begin{array}{l}0.8 \\
6\end{array}$ & $\begin{array}{l}0.1 \\
4\end{array}$ \\
\hline 2013 & 331 & $\begin{array}{l}0.1 \\
5\end{array}$ & 4.60 & 0.89 & $\begin{array}{l}0.1 \\
1\end{array}$ & 128 & $\begin{array}{l}0.2 \\
2\end{array}$ & $\begin{array}{l}3.0 \\
9\end{array}$ & $\begin{array}{l}1.3 \\
1\end{array}$ & $\begin{array}{l}0.3 \\
1\end{array}$ & 225 & $\begin{array}{l}0.2 \\
0\end{array}$ & $\begin{array}{l}3.5 \\
5\end{array}$ & $\begin{array}{l}1.2 \\
3\end{array}$ & $\begin{array}{l}0.2 \\
3\end{array}$ \\
\hline 2014 & 402 & $\begin{array}{l}0.1 \\
6\end{array}$ & 4.42 & 1.21 & $\begin{array}{l}0.2 \\
1\end{array}$ & 200 & $\begin{array}{l}0.2 \\
7\end{array}$ & $\begin{array}{l}2.5 \\
4\end{array}$ & $\begin{array}{l}1.5 \\
6\end{array}$ & $\begin{array}{l}0.5 \\
6\end{array}$ & 277 & $\begin{array}{l}0.2 \\
0\end{array}$ & $\begin{array}{l}3.5 \\
1\end{array}$ & $\begin{array}{l}1.2 \\
3\end{array}$ & $\begin{array}{l}0.2 \\
3\end{array}$ \\
\hline 2015 & 411 & $\begin{array}{l}0.1 \\
4 \\
\end{array}$ & 5.01 & 1.02 & $\begin{array}{l}0.0 \\
2 \\
\end{array}$ & 184 & $\begin{array}{l}0.2 \\
0\end{array}$ & $\begin{array}{l}3.4 \\
9\end{array}$ & $\begin{array}{l}0.9 \\
2\end{array}$ & $\begin{array}{l}0.0 \\
8\end{array}$ & 318 & $\begin{array}{l}0.1 \\
9\end{array}$ & $\begin{array}{l}3.7 \\
1\end{array}$ & $\begin{array}{l}1.1 \\
5\end{array}$ & $\begin{array}{l}0.1 \\
5\end{array}$ \\
\hline 2016 & 349 & $\begin{array}{l}0.1 \\
0\end{array}$ & 6.65 & 0.85 & $\begin{array}{l}0.1 \\
5\end{array}$ & 116 & $\begin{array}{l}0.1 \\
1\end{array}$ & $\begin{array}{l}6.4 \\
5\end{array}$ & $\begin{array}{l}0.6 \\
3\end{array}$ & $\begin{array}{l}0.3 \\
7\end{array}$ & 212 & $\begin{array}{l}0.1 \\
1\end{array}$ & $\begin{array}{l}6.4 \\
4\end{array}$ & $\begin{array}{l}0.6 \\
7\end{array}$ & $\begin{array}{l}0.3 \\
3\end{array}$ \\
\hline 2017 & 325 & $\begin{array}{l}0.0 \\
9\end{array}$ & 7.87 & 0.93 & $\begin{array}{l}0.0 \\
7\end{array}$ & 87 & $\begin{array}{l}0.0 \\
7\end{array}$ & $\begin{array}{l}9.4 \\
1\end{array}$ & $\begin{array}{l}0.7 \\
5\end{array}$ & $\begin{array}{l}0.2 \\
5\end{array}$ & 197 & $\begin{array}{l}0.0 \\
9\end{array}$ & $\begin{array}{l}7.6 \\
5\end{array}$ & $\begin{array}{l}0.9 \\
3\end{array}$ & $\begin{array}{l}0.0 \\
7\end{array}$ \\
\hline 2018 & 397 & $\begin{array}{l}0.1 \\
0\end{array}$ & 7.07 & 1.22 & $\begin{array}{l}0.2 \\
2\end{array}$ & 109 & $\begin{array}{l}0.0 \\
9\end{array}$ & $\begin{array}{l}8.1 \\
3\end{array}$ & $\begin{array}{l}1.2 \\
5\end{array}$ & $\begin{array}{l}0.2 \\
5\end{array}$ & 258 & $\begin{array}{l}0.1 \\
1\end{array}$ & $\begin{array}{l}6.4 \\
5\end{array}$ & $\begin{array}{l}1.3 \\
1\end{array}$ & $\begin{array}{l}0.3 \\
1\end{array}$ \\
\hline 2019 & 412 & $\begin{array}{l}0.0 \\
9\end{array}$ & 7.49 & 1.04 & $\begin{array}{l}0.0 \\
4\end{array}$ & 122 & $\begin{array}{l}0.0 \\
9\end{array}$ & $\begin{array}{l}7.9 \\
2\end{array}$ & $\begin{array}{l}1.1 \\
2\end{array}$ & $\begin{array}{l}0.1 \\
2\end{array}$ & 206 & $\begin{array}{l}0.0 \\
8\end{array}$ & $\begin{array}{l}8.8 \\
6\end{array}$ & $\begin{array}{l}0.8 \\
0\end{array}$ & $\begin{array}{l}0.2 \\
0\end{array}$ \\
\hline
\end{tabular}

Table 1: Year wise Growth of Publications

As shown in the table 1, 4223 records were published by PSG College of Technology, and there is an increasing trend from the year 2005 onwards with the relative growth rate of 0.45, average years of publication 7.29. Whereas Coimbatore Institute of Technology, Coimbatore has published 1461 documents with average year of publication 6.7 and Thiagarajar College of Engineering, Madurai has 2739 records of publication in its credit with the average year of publication is 6.78. It is clearly evident that PSG College of Technology has a good record of publications with the relative growth rate.

\section{Authorship pattern and Degree of Collaboration}


Table 2 identifies the Authorship pattern, degree of collaboration, Collaborative Author Index, Average Authors per Paper and Authors Productivity efficiency. PSG College of Technology has 4442 authors work in its credit which includes 81 single authors, 4361 multiple authored documents. 0.95 documents per author is getting published with 1.05 authors per document and 1.07 collaborative index. Whereas Coimbatore Institute of Technology has 1600 authors contributed in which 12 single authored documents, 1588 multi authored documents.CIT has collaboration index of 1.1. 2914 authors are involved the research productivity of Thiagarajar College of Engineering in which 21 are single authored documents, 2893 is multi authored documents, 0.94 documents per author, 1.06 authors per document and 1.07 is the collaboration index.

\begin{tabular}{|c|c|c|c|c|c|c|c|c|c|c|}
\hline Year & $\begin{array}{l}\text { Total } \\
\text { articles }\end{array}$ & $\begin{array}{l}\text { No of } \\
\text { authors }\end{array}$ & $\begin{array}{l}\text { Single } \\
\text { Author }\end{array}$ & CAI & $\begin{array}{l}\text { More } \\
\text { than } \\
\text { Two } \\
\text { Authors }\end{array}$ & CAI & DC & RSA & AAPP & PPA \\
\hline PSG & 4223 & 4442 & 81 & 52.49 & 4361 & 164.05 & 1.03 & 0.02 & 1.05 & 0.95 \\
\hline CIT & 1461 & 1600 & 12 & 21.59 & 1588 & 165.85 & 0.22 & 0.00 & 1.10 & 0.91 \\
\hline TCE & 2739 & 2914 & 21 & 20.74 & 2893 & 165.90 & 1.06 & 0.01 & 1.06 & 0.94 \\
\hline
\end{tabular}

Table 2. Authorship pattern and Degree of Collaboration

The above table shows Thiagarajar College of Engineering has the degree of collaboration of 1.06 followed by PSG College of Technology 1.03 and 0.22 Coimbatore Institute of Technology.

Most Prolific Authors of Institutions

Table 3 describes the most prolific authors of the studied institutions with number of articles published and fractionalization of articles by the author of the institutions.

\begin{tabular}{|c|c|c|c|c|c|c|c|c|}
\hline \multicolumn{3}{|l|}{ PSG } & \multicolumn{3}{|l|}{ CIT } & \multicolumn{3}{|l|}{ TCE } \\
\hline Authors & $\begin{array}{l}\text { Art } \\
\text { icle } \\
\text { s } \\
\end{array}$ & $\begin{array}{l}\text { Artic } \\
\text { les } \\
\text { Frac } \\
\text { tiona } \\
\text { lized }\end{array}$ & Authors & $\begin{array}{l}\text { Art } \\
\text { icle } \\
\text { s } \\
\end{array}$ & $\begin{array}{l}\text { Artic } \\
\text { les } \\
\text { Frac } \\
\text { tiona } \\
\text { lized }\end{array}$ & Authors & $\begin{array}{l}\text { Art } \\
\text { icle } \\
\text { s } \\
\end{array}$ & $\begin{array}{l}\text { Articl } \\
\text { es } \\
\text { Fracti } \\
\text { onaliz } \\
\text { ed }\end{array}$ \\
\hline DEVADASAN SR & 155 & 40.24 & $\begin{array}{l}\text { MUTHUKUMARAS } \\
\text { AMY N }\end{array}$ & 163 & 35.38 & BASKAR S & 95 & 32.90 \\
\hline SIVANANDAM SN & 114 & 46.20 & MURUGAN N & 131 & 49.74 & VENKATESH P & 85 & 27.87 \\
\hline THILAGAVATHI G & 105 & 44.15 & SELLADURAI V & 82 & 29.47 & SUKANESH R & 82 & 34.22 \\
\hline RAJASEKARAN S & 83 & 51.45 & AGILAN S & 80 & 16.15 & RAJARAM S & 81 & 31.03 \\
\hline $\begin{array}{l}\text { RAMACHANDRA } \\
\mathrm{N} \mathrm{T}\end{array}$ & 83 & 28.58 & $\begin{array}{l}\text { BALASUNDARAP } \\
\text { RABHU R }\end{array}$ & 72 & 14.58 & $\begin{array}{l}\text { THIRUVENGAD } \\
\text { AM SJ }\end{array}$ & 79 & 28.47 \\
\hline $\begin{array}{l}\text { BALASUNDARAP } \\
\text { RABHU R }\end{array}$ & 81 & 16.18 & $\begin{array}{l}\text { VELAUTHAPILLAI } \\
\text { D }\end{array}$ & 68 & 12.68 & KAMARAJ N & 76 & 30.53 \\
\hline SUMATHI S & 80 & 35.00 & THAMBIDURAI M & 57 & 10.87 & $\begin{array}{l}\text { BALAMURUGA } \\
\text { N NB }\end{array}$ & 73 & 27.49 \\
\hline JEROME J & 75 & 28.58 & $\begin{array}{l}\text { THIRUMARIMURU } \\
\text { GAN M }\end{array}$ & 46 & 13.22 & SHALINIE SM & 67 & 28.75 \\
\hline KRISHNARAJ V & 74 & 23.31 & SENTHIL TS & 44 & 10.44 & RAJU S & 60 & 17.19 \\
\hline $\begin{array}{l}\text { MUTHUKUMARA } \\
\text { SAMY N }\end{array}$ & 72 & 14.48 & RAJESWARI A & 42 & 17.70 & JAWAHAR N & 59 & 21.45 \\
\hline
\end{tabular}

Table 3. Most Prolific Authors of Institutions 


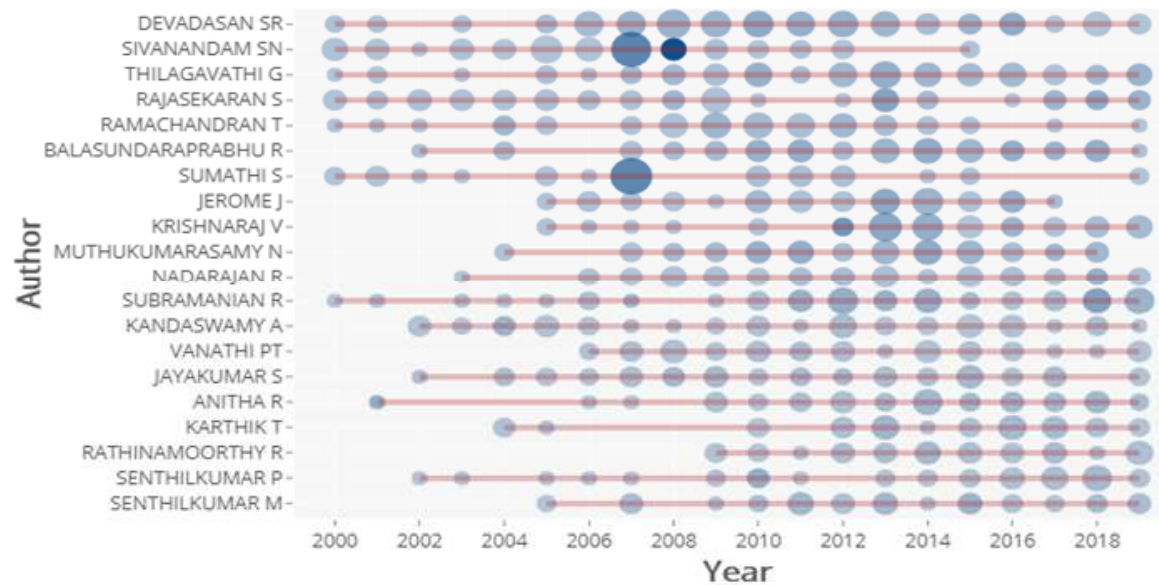

Figure 1. PSG -Top 10 Authors Productivity over the period (2000-2019)

Figure 1 shows Dr.S R Devadasan is the most prolific author of PSG College of Technology over the period with 155 articles, followed by Dr.S N Sivanandam 115 articles and Dr.G Thilagavathi 105 documents in their credits.

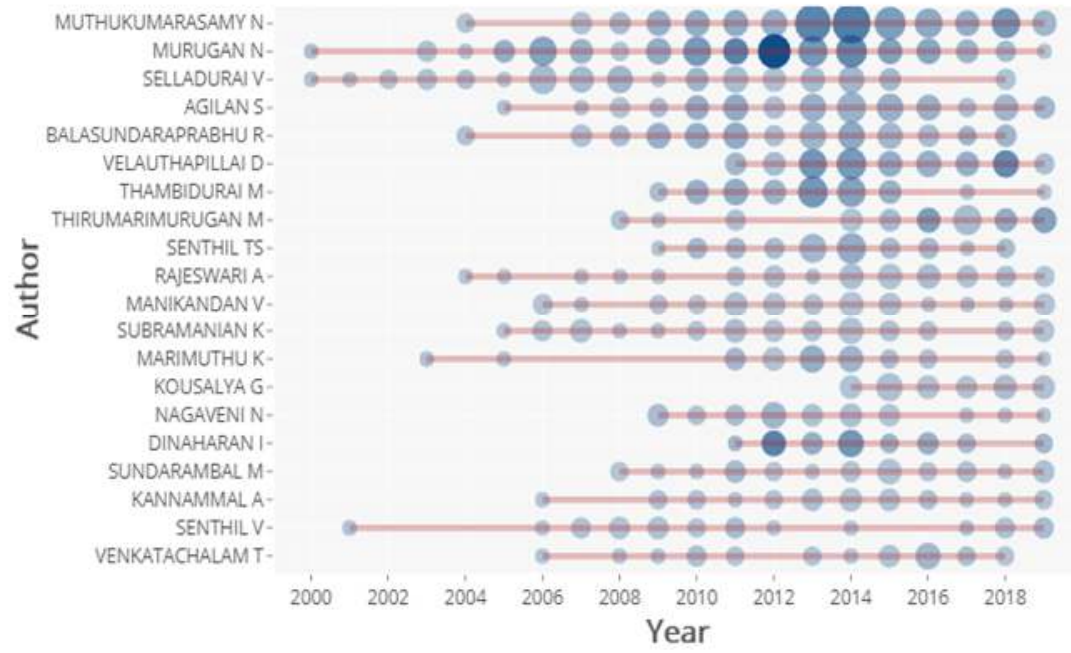

Figure 2. CIT -Top 10 Authors Productivity over the period (2000-2019)

Figure 2 shows Dr.N Muthukumarasamy is the most prolific author of Coimbatore Institute of Technology over the period with 163 articles, followed by Dr. N Murugan 131 articles and Dr.V Selladurai 82 documents in their credits. 


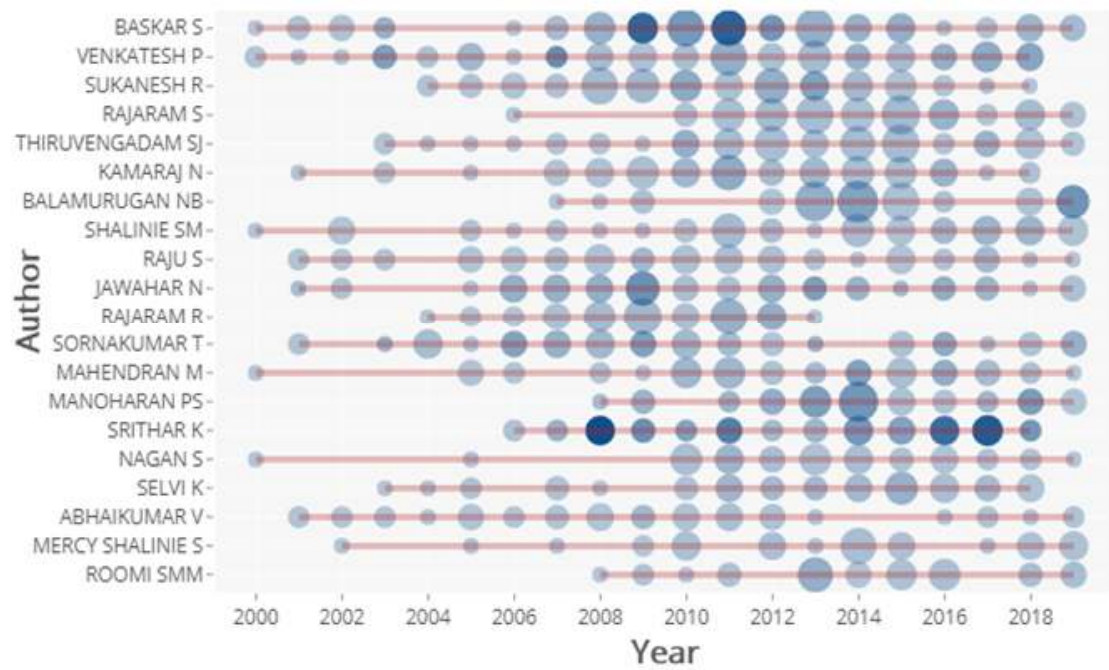

Figure 3. TCE - Top 10 Authors Productivity over the period (2000-2019)

Figure 3 shows Dr.S Baskar is the most prolific author of Thiagarajar College of Engineering over the period with 95 articles, followed by Dr. P Venkatesh 85 articles and Dr.R Sukanesh 82 documents in their credits.

\section{Predominant Source of Publication}

Table 4 describes the predominant source of publications by the analyzed institutions for the study period. International Journal of Applied Engineering Research is the most preferred journal by all three institutions

\begin{tabular}{|c|c|c|c|c|c|}
\hline \multicolumn{2}{|l|}{ PSG } & \multicolumn{2}{|l|}{ CIT } & \multicolumn{2}{|l|}{ TCE } \\
\hline Sources & Articles & Sources & Articles & Sources & Articles \\
\hline $\begin{array}{l}\text { INTERNATIONAL } \\
\text { JOURNAL OF APPLIED } \\
\text { ENGINEERING } \\
\text { RESEARCH }\end{array}$ & 97 & $\begin{array}{l}\text { INTERNATIONAL } \\
\text { JOURNAL OF APPLIED } \\
\text { ENGINEERING } \\
\text { RESEARCH }\end{array}$ & 62 & $\begin{array}{l}\text { INTERNATIONAL } \\
\text { JOURNAL OF APPLIED } \\
\text { ENGINEERING } \\
\text { RESEARCH }\end{array}$ & 103 \\
\hline $\begin{array}{l}\text { INDIAN JOURNAL OF } \\
\text { FIBRE AND TEXTILE } \\
\text { RESEARCH }\end{array}$ & 83 & $\begin{array}{lr}\text { EUROPEAN } & \text { JOURNAL } \\
\text { OF } & \text { SCIENTIFIC } \\
\text { RESEARCH } & \\
\end{array}$ & 32 & $\begin{array}{l}\text { LECTURE NOTES IN } \\
\text { COMPUTER SCIENCE }\end{array}$ & 38 \\
\hline $\begin{array}{lr}\text { EUROPEAN } & \text { JOURNAL } \\
\text { OF } & \text { SCIENTIFIC } \\
\text { RESEARCH } & \end{array}$ & 59 & $\begin{array}{l}\text { ADVANCED } \\
\text { MATERIALS RESEARCH }\end{array}$ & 21 & \begin{tabular}{ll}
\multicolumn{2}{l}{ COMMUNICATIONS IN } \\
COMPUTER AND \\
INFORMATION \\
SCIENCE
\end{tabular} & 36 \\
\hline $\begin{array}{l}\text { ASIAN } \\
\text { JOURNAL }\end{array}$ & 58 & $\begin{array}{lr}\text { JOURNAL } & \text { OF } \\
\text { MATERIALS } & \text { SCIENCE: } \\
\text { MATERIALS } & \text { IN } \\
\text { ELECTRONICS } & \end{array}$ & 21 & $\begin{array}{lr}\text { ADVANCES } & \text { IN } \\
\text { INTELLIGENT } & \\
\text { SYSTEMS } & \text { AND } \\
\text { COMPUTING } & \end{array}$ & 35 \\
\hline $\begin{array}{l}\text { MAN-MADE } \\
\text { IN INDIA }\end{array}$ & 48 & $\begin{array}{l}\text { PROCEDIA COMPUTER } \\
\text { SCIENCE }\end{array}$ & 20 & $\begin{array}{l}\text { EUROPEAN JOURNAL } \\
\text { OF SCIENTIFIC } \\
\text { RESEARCH }\end{array}$ & 30 \\
\hline $\begin{array}{l}\text { STUDIES } \\
\text { COMPUTATIONAL } \\
\text { INTELLIGENCE }\end{array}$ & 48 & $\begin{array}{l}\text { ADVANCES IN } \\
\text { INTELLIGENT SYSTEMS } \\
\text { AND COMPUTING }\end{array}$ & 16 & $\begin{array}{lr}\text { JOURNAL OF } & \text { THE } \\
\text { INSTITUTION } & \text { OF } \\
\text { ENGINEERS } & \text { (INDIA): } \\
\text { ELECTRICAL } & \\
\text { ENGINEERING } & \end{array}$ & 30 \\
\hline
\end{tabular}




\begin{tabular}{|c|c|c|c|c|c|}
\hline & & & & DIVISION & \\
\hline $\begin{array}{lr}\text { JOURNAL } & \text { OF } \\
\text { SCIENTIFIC } & \text { AND } \\
\text { INDUSTRIAL RESEARCH }\end{array}$ & 44 & $\begin{array}{l}\text { MATERIALS AND } \\
\text { DESIGN }\end{array}$ & 14 & $\begin{array}{ll}\text { LECTURE NOTES IN } \\
\text { ELECTRICAL } \\
\text { ENGINEERING }\end{array}$ & 21 \\
\hline $\begin{array}{l}\text { COMMUNICATIONS IN } \\
\text { COMPUTER AND } \\
\text { INFORMATION SCIENCE }\end{array}$ & 39 & CLUSTER COMPUTING & 13 & $\begin{array}{l}\text { APPLIED MECHANICS } \\
\text { AND MATERIALS }\end{array}$ & 20 \\
\hline $\begin{array}{lr}\text { JOURNAL OF } & \text { THE } \\
\text { INSTITUTION } & \text { OF } \\
\text { ENGINEERS } & \text { (INDIA) } \\
\text { PART TX: } & \text { TEXTILE } \\
\text { ENGINEERING DIVISION }\end{array}$ & 36 & $\begin{array}{l}\text { INTERNATIONAL } \\
\text { JOURNAL OF } \\
\text { CHEMTECH RESEARCH }\end{array}$ & 13 & $\begin{array}{ll}\text { INTERNATIONAL } & \\
\text { REVIEW } & \text { OF } \\
\text { ELECTRICAL } & \\
\text { ENGINEERING } & \\
\end{array}$ & 19 \\
\hline $\begin{array}{lcc}\text { JOURNAL } & \text { OF } & \text { THE } \\
\text { TEXTILE INSTITUTE }\end{array}$ & 36 & OPTIK & 13 & $\begin{array}{l}\text { AIP CONFERENCE } \\
\text { PROCEEDINGS }\end{array}$ & 18 \\
\hline
\end{tabular}

Table 4. Predominant Source of Publication

Institutional Source Impact

The below table shows the most institutions source impact for PSG College of Technology with the parameters of h-index, g-index, m-index, Total citations and number of publications. International Journal of Applied Engineering Research is most impactful source with h-index of 4 and total citation of 39, International Journal of Fibre and Textile Research has h-index 16 and total citation of 829 followed by European Journal of Scientific Research with 253 citations.

\begin{tabular}{|c|c|c|c|c|c|c|}
\hline \multicolumn{7}{|l|}{ PSG College of Technology- Source Impact } \\
\hline Source & $\begin{array}{l}\text { h- } \\
\text { index }\end{array}$ & $\begin{array}{l}\text { g_ } \\
\text { index }\end{array}$ & $\begin{array}{l}\text { m } \\
\text { index }\end{array}$ & TC & $\begin{array}{l}\mathbf{N} \\
\mathbf{P}\end{array}$ & $\begin{array}{l}\text { PY } \\
\text { start }\end{array}$ \\
\hline $\begin{array}{l}\text { INTERNATIONAL JOURNAL OF APPLIED } \\
\text { ENGINEERING RESEARCH }\end{array}$ & 4 & 4 & 0.4 & 39 & 97 & 2011 \\
\hline $\begin{array}{l}\text { INDIAN JOURNAL OF FIBRE AND TEXTILE } \\
\text { RESEARCH }\end{array}$ & 16 & 24 & 0.76 & 829 & 83 & 2000 \\
\hline $\begin{array}{l}\text { EUROPEAN JOURNAL OF SCIENTIFIC } \\
\text { RESEARCH }\end{array}$ & 8 & 14 & 0.57 & 253 & 59 & 2007 \\
\hline ASIAN TEXTILE JOURNAL & 4 & 4 & 0.19 & 53 & 58 & 2000 \\
\hline MAN-MADE TEXTILES IN INDIA & 4 & 4 & 0.2 & 30 & 48 & 2001 \\
\hline $\begin{array}{l}\text { STUDIES IN COMPUTATIONAL } \\
\text { INTELLIGENCE }\end{array}$ & 4 & 5 & 0.28 & 48 & 48 & 2007 \\
\hline $\begin{array}{l}\text { JOURNAL OF SCIENTIFIC AND INDUSTRIAL } \\
\text { RESEARCH }\end{array}$ & 6 & 10 & 0.375 & 175 & 44 & 2005 \\
\hline $\begin{array}{l}\text { COMMUNICATIONS IN COMPUTER AND } \\
\text { INFORMATION SCIENCE }\end{array}$ & 6 & 10 & 0.54 & 133 & 39 & 2010 \\
\hline $\begin{array}{l}\text { JOURNAL OF THE INSTITUTION OF } \\
\text { ENGINEERS (INDIA), PART TX: TEXTILE } \\
\text { ENGINEERING DIVISION }\end{array}$ & 4 & 14 & 0.19 & 223 & 36 & 2000 \\
\hline JOURNAL OF THE TEXTILE INSTITUTE & 11 & 16 & 0.78 & 351 & 36 & 2007 \\
\hline APPLIED MECHANICS AND MATERIALS & 4 & 4 & 0.44 & 38 & 34 & 2012 \\
\hline ASIAN DYER & 4 & 4 & 0.28 & 27 & 32 & 2007 \\
\hline
\end{tabular}

Table 5. PSG College of Technology- Source Impact

Table 6 shows source impact for Coimbatore Institute of Technology with the parameters of h-index, g-index, m-index, Total citations and number of publications. International Journal of Applied Engineering Research is most impactful source with h-index of 2 and total 
citation of 15, Journal of Materials Science: Materials in Electronics has h-index 11 and total citation of 276 followed by European Journal of Scientific Research with 118 citations.

\begin{tabular}{|c|c|c|c|c|c|c|}
\hline \multicolumn{7}{|l|}{ Coimbatore Institute of Technology-- Source Impact } \\
\hline$y^{2}$ & $\mathbf{h}_{\mathbf{x}}$ inde & g index & $m$ index & TC & NP & $\begin{array}{l}\text { PY } \\
\text { start }\end{array}$ \\
\hline $\begin{array}{l}\text { INTERNATIONAL JOURNAL OF APPLIED } \\
\text { ENGINEERING RESEARCH }\end{array}$ & 2 & 2 & 0.28 & 15 & 62 & 2014 \\
\hline EUROPEAN JOURNAL OF SCIENTIFIC RESEARCH & 7 & 9 & 0.58 & 118 & 32 & 2009 \\
\hline ADVANCED MATERIALS RESEARCH & 4 & 4 & 0.33 & 32 & 21 & 2009 \\
\hline $\begin{array}{l}\text { JOURNAL OF MATERIALS SCIENCE: MATERIALS } \\
\text { IN ELECTRONICS }\end{array}$ & 11 & 16 & 1.1 & 276 & 21 & 2011 \\
\hline PROCEDIA COMPUTER SCIENCE & 7 & 11 & 0.63 & 137 & 20 & 2010 \\
\hline $\begin{array}{l}\text { ADVANCES IN INTELLIGENT SYSTEMS AND } \\
\text { COMPUTING }\end{array}$ & 3 & 5 & 0.375 & 36 & 16 & 2013 \\
\hline MATERIALS AND DESIGN & 14 & 14 & 1.16 & 1078 & 14 & 2009 \\
\hline CLUSTER COMPUTING & 2 & 3 & 0.66 & 19 & 13 & 2018 \\
\hline $\begin{array}{l}\text { INTERNATIONAL JOURNAL OF CHEMTECH } \\
\text { RESEARCH }\end{array}$ & 5 & 6 & 0.41 & 49 & 13 & 2009 \\
\hline OPTIK & 8 & 13 & 1 & 199 & 13 & 2013 \\
\hline $\begin{array}{l}\text { PROCEEDINGS OF } 2011 \text { INTERNATIONAL } \\
\text { CONFERENCE ON PROCESS AUTOMATION, } \\
\text { CONTROL AND COMPUTING, PACC } 2011\end{array}$ & 4 & 7 & 0.4 & 57 & 13 & 2011 \\
\hline SUPERLATTICES AND MICROSTRUCTURES & 9 & 12 & 1.28 & 154 & 13 & 2014 \\
\hline
\end{tabular}

Table 6. Coimbatore Institute of Technology- Source Impact

Table 7 shows source impact for Thiagarajar College of Engineering publications. International Journal of Applied Engineering Research is most impactful source with h-index of 2 and total citation of 21 Journal of the Institution of Engineers (India): Electrical Engineering Division has h-index 9 and total citation of 186 followed by European Journal of Scientific Research with 105citations.

\begin{tabular}{|c|c|c|c|c|c|c|}
\hline $\begin{array}{l}\text { Thiagar } \\
\text { Source }\end{array}$ & $\begin{array}{l}h_{-} \\
\text {index }\end{array}$ & $\begin{array}{ll}g_{-} \\
\text {index }\end{array}$ & $\begin{array}{l}\text { m } \\
\text { index }\end{array}$ & TC & NP & $\begin{array}{l}\text { PY } \\
\text { start }\end{array}$ \\
\hline $\begin{array}{l}\text { INTERNATIONAL JOURNAL OF APPLIED } \\
\text { ENGINEERING RESEARCH }\end{array}$ & 2 & 2 & 0.25 & 21 & 103 & 2013 \\
\hline $\begin{array}{l}\text { LECTURE NOTES IN COMPUTER SCIENCE } \\
\text { (INCLUDING SUBSERIES LECTURE NOTES IN } \\
\text { ARTIFICIAL INTELLIGENCE AND LECTURE } \\
\text { NOTES IN BIOINFORMATICS) }\end{array}$ & 4 & 6 & 0.25 & 76 & 38 & 2005 \\
\hline $\begin{array}{l}\text { COMMUNICATIONS IN COMPUTER AND } \\
\text { INFORMATION SCIENCE }\end{array}$ & 4 & 5 & 0.33 & 54 & 36 & 2009 \\
\hline $\begin{array}{l}\text { ADVANCES IN INTELLIGENT SYSTEMS AND } \\
\text { COMPUTING }\end{array}$ & 4 & 4 & 0.57 & 53 & 35 & 2014 \\
\hline EUROPEAN JOURNAL OF SCIENTIFIC RESEARCH & 6 & 9 & 0.5 & 105 & 30 & 2009 \\
\hline $\begin{array}{l}\text { JOURNAL OF THE INSTITUTION OF ENGINEERS } \\
\text { (INDIA): ELECTRICAL ENGINEERING DIVISION }\end{array}$ & 9 & 12 & 0.43 & 186 & 30 & 2000 \\
\hline LECTURE NOTES IN ELECTRICAL ENGINEERING & 3 & 4 & 0.375 & 26 & 21 & 2013 \\
\hline APPLIED MECHANICS AND MATERIALS & 3 & 3 & 0.33 & 30 & 20 & 2012 \\
\hline $\begin{array}{l}\text { INTERNATIONAL REVIEW OF ELECTRICAL } \\
\text { ENGINEERING }\end{array}$ & 4 & 5 & 0.4 & 56 & 19 & 2011 \\
\hline
\end{tabular}




\begin{tabular}{|l|l|l|l|l|l|l|}
\hline AIP CONFERENCE PROCEEDINGS & 2 & 2 & 0.18 & 12 & 18 & 2010 \\
\hline $\begin{array}{l}\text { 2018 NATIONAL POWER ENGINEERING } \\
\text { CONFERENCE, NPEC 2018 }\end{array}$ & 2 & 2 & 0.66 & 12 & 17 & 2018 \\
\hline \begin{tabular}{l} 
APPLIED SOFT COMPUTING JOURNAL \\
\hline
\end{tabular} & 12 & 17 & 0.66 & 645 & 17 & 2003 \\
\hline
\end{tabular}

Table 7.Thiagarajar College of Engineering-- Source Impact

\section{Predominant Collaborative Institutions}

Table 8 shows the predominant collaborative institutions by the institutions of study. PSG College of Technology has collaborated more with Coimbatore Institute of Technology, Anna University, Kumaraguru College of Technology and so on. Coimbatore Institute of Technology has affiliated vise versa with PSG College of Technology, Anna University, Government College of Technology, Coimbatore. Thiagarajar College of Engineering has published more articles with Anna University, Sethu Institute of Technology and Velammal College of Engineering and Technology respectively.

\begin{tabular}{|c|c|c|c|c|c|}
\hline \multicolumn{2}{|l|}{ PSG } & \multicolumn{2}{|l|}{ CIT } & \multicolumn{2}{|l|}{ TCE } \\
\hline Affiliations & Articles & Affiliations & Articles & Affiliations & Articles \\
\hline $\begin{array}{l}\text { COIMBATORE } \\
\text { INSTITUTE } \\
\text { TECHNOLOGY }\end{array}$ & 180 & $\begin{array}{l}\text { PSG COLLEGE OF } \\
\text { TECHNOLOGY }\end{array}$ & 161 & ANNA UNIVERSITY & 167 \\
\hline ANNA UNIVERSITY & 159 & ANNA UNIVERSITY & 83 & $\begin{array}{l}\text { SETHU INSTITUTE } \\
\text { OF TECHNOLOGY }\end{array}$ & 85 \\
\hline $\begin{array}{l}\text { KUMARAGURU } \\
\text { COLLEGE } \\
\text { TECHNOLOGY }\end{array}$ & 128 & $\begin{array}{l}\text { GOVERNMENT } \\
\text { COLLEGE } \\
\text { TECHNOLOGY }\end{array}$ & 55 & $\begin{array}{l}\text { VELAMMAL } \\
\text { COLLEGE OF } \\
\text { ENGINEERING AND } \\
\text { TECHNOLOGY }\end{array}$ & 61 \\
\hline $\begin{array}{lr}\text { BANNARI } & \text { AMMAN } \\
\text { INSTITUTE } & \text { OF } \\
\text { TECHNOLOGY } & \\
\end{array}$ & 99 & $\begin{array}{ll}\text { UNIVERSITY } & \\
\text { COLLEGE } & \text { OF } \\
\text { BERGEN } & \\
\end{array}$ & 50 & $\begin{array}{l}\text { K.L.N. COLLEGE OF } \\
\text { ENGINEERING }\end{array}$ & 58 \\
\hline $\begin{array}{l}\text { PSG INSTITUTE OF } \\
\text { ADVANCED STUDIES }\end{array}$ & 99 & $\begin{array}{l}\text { KARUNYA } \\
\text { UNIVERSITY }\end{array}$ & 42 & $\begin{array}{l}\text { KAMARAJ } \\
\text { COLLEGE OF } \\
\text { ENGINEERING AND } \\
\text { TECHNOLOGY }\end{array}$ & 58 \\
\hline $\begin{array}{l}\text { PSG COLLEGE OF ARTS } \\
\text { AND SCIENCE }\end{array}$ & 61 & $\begin{array}{ll}\text { KUMARAGURU } & \\
\text { COLLEGE } & \text { OF } \\
\text { TECHNOLOGY } & \\
\end{array}$ & 40 & $\begin{array}{l}\text { MEPCO SCHLENK } \\
\text { ENGINEERING } \\
\text { COLLEGE }\end{array}$ & 55 \\
\hline $\begin{array}{l}\text { NATIONAL INSTITUTE } \\
\text { OF TECHNOLOGY }\end{array}$ & 59 & $\begin{array}{l}\text { BHARATHIAR } \\
\text { UNIVERSITY }\end{array}$ & 37 & $\begin{array}{l}\text { KALASALINGAM } \\
\text { UNIVERSITY }\end{array}$ & 33 \\
\hline $\begin{array}{l}\text { BHARATHIAR } \\
\text { UNIVERSITY }\end{array}$ & 50 & $\begin{array}{l}\text { ERODE } \\
\text { SENGUNTHAR } \\
\text { ENGINEERING } \\
\text { COLLEGE }\end{array}$ & 36 & $\begin{array}{l}\text { MADURAI } \\
\text { KAMARAJ } \\
\text { UNIVERSITY }\end{array}$ & 32 \\
\hline $\begin{array}{l}\text { KARPAGAM COLLEGE } \\
\text { OF ENGINEERING }\end{array}$ & 48 & $\begin{array}{l}\text { SEOUL NATIONAL } \\
\text { UNIVERSITY }\end{array}$ & 29 & VIT UNIVERSITY & 26 \\
\hline $\begin{array}{l}\text { PSG INSTITUTE OF } \\
\text { TECHNOLOGY AND } \\
\text { APPLIED RESEARCH }\end{array}$ & 46 & $\begin{array}{l}\text { KONGU } \\
\text { ENGINEERING } \\
\text { COLLEGE }\end{array}$ & 28 & $\begin{array}{l}\text { SYED AMMAL } \\
\text { ENGINEERING } \\
\text { COLLEGE }\end{array}$ & 23 \\
\hline
\end{tabular}

Table 8. Predominant Collaborative Institutions

\section{Collaborative Countries}

Table 9 describes the institution publications collaborated with other countries. PSG College of Technology has collaborated with Iran, China, and USA and so on. Coimbatore Institute of Technology has collaborated with Korea, Mexico and USA. Thiagarajar College of Engineering has collaborated with Malaysia, Singapore, and USA and so on. 


\begin{tabular}{|c|c|c|c|c|c|c|c|c|c|c|c|c|c|c|c|c|c|}
\hline \multicolumn{6}{|l|}{ PSG } & \multicolumn{6}{|l|}{ CIT } & \multicolumn{6}{|l|}{ TCE } \\
\hline Country & $\begin{array}{l}\text { Articl } \\
\text { es }\end{array}$ & Freq & SCP & $\begin{array}{l}\text { MC } \\
\mathbf{P}\end{array}$ & $\begin{array}{l}\text { MCP } \\
\text { Rati } \\
\text { o }\end{array}$ & $\begin{array}{l}\text { Cou } \\
\text { ntry }\end{array}$ & $\begin{array}{l}\text { Art } \\
\text { icle } \\
\text { s }\end{array}$ & $\begin{array}{l}\text { Fr } \\
\text { eq }\end{array}$ & SCP & $\begin{array}{l}\text { M } \\
\text { CP }\end{array}$ & $\begin{array}{l}\text { MCP } \\
\text {-Rati } \\
\text { o }\end{array}$ & $\begin{array}{l}\text { Coun } \\
\text { try }\end{array}$ & $\begin{array}{l}\text { Arti } \\
\text { cles }\end{array}$ & $\begin{array}{l}\text { Fre } \\
q\end{array}$ & SCP & $\begin{array}{l}\text { M } \\
\text { CP }\end{array}$ & $\begin{array}{l}\text { MC } \\
\text { P_R } \\
\text { atio }\end{array}$ \\
\hline INDIA & 2156 & 0.97073 & 2049 & 107 & 0.04 & $\begin{array}{l}\text { INDI } \\
\mathrm{A}\end{array}$ & 682 & $\begin{array}{l}0.9 \\
30 \\
42\end{array}$ & 629 & 53 & 0.07 & $\begin{array}{l}\text { INDI } \\
\text { A }\end{array}$ & 1273 & $\begin{array}{l}0.9 \\
636 \\
64 \\
\end{array}$ & 1205 & 68 & 0.05 \\
\hline IRAN & 16 & 0.0072 & 0 & 16 & 1 & $\begin{array}{l}\text { KOR } \\
\text { EA }\end{array}$ & 33 & $\begin{array}{l}0.0 \\
45 \\
02 \\
\end{array}$ & 0 & 33 & 1 & $\begin{array}{l}\text { MAL } \\
\text { AYSI } \\
\text { A }\end{array}$ & 22 & $\begin{array}{l}0.0 \\
166 \\
54\end{array}$ & 0 & 22 & 1 \\
\hline CHINA & 9 & 0.00405 & 0 & 9 & 1 & $\begin{array}{l}\text { MEX } \\
\text { ICO }\end{array}$ & 4 & $\begin{array}{l}0.0 \\
05 \\
46\end{array}$ & 0 & 4 & 1 & USA & 5 & $\begin{array}{l}0.0 \\
037 \\
85\end{array}$ & 0 & 5 & 1 \\
\hline USA & 9 & 0.00405 & 1 & 8 & 0.88 & USA & 4 & $\begin{array}{l}0.0 \\
05 \\
46\end{array}$ & 0 & 4 & 1 & $\begin{array}{l}\text { SING } \\
\text { APO } \\
\text { RE }\end{array}$ & 4 & $\begin{array}{l}0.0 \\
030 \\
28\end{array}$ & 0 & 4 & 1 \\
\hline KOREA & 6 & 0.0027 & 0 & 6 & 1 & $\begin{array}{l}\text { NOR } \\
\text { WA } \\
\text { Y }\end{array}$ & 3 & $\begin{array}{l}0.0 \\
04 \\
09\end{array}$ & 0 & 3 & 1 & $\begin{array}{l}\text { AUST } \\
\text { RALI } \\
\text { A }\end{array}$ & 3 & $\begin{array}{l}0.0 \\
022 \\
71\end{array}$ & 0 & 3 & 1 \\
\hline CANADA & 3 & 0.00135 & 0 & 3 & 1 & $\begin{array}{l}\text { SAU } \\
\text { DI } \\
\text { ARA } \\
\text { BIA }\end{array}$ & 2 & $\begin{array}{l}0.0 \\
02 \\
73\end{array}$ & 0 & 2 & 1 & $\begin{array}{l}\text { SOUT } \\
\mathrm{H} \\
\text { AFRI } \\
\text { CA }\end{array}$ & 3 & $\begin{array}{l}0.0 \\
022 \\
71\end{array}$ & 0 & 3 & 1 \\
\hline FRANCE & 3 & 0.00135 & 0 & 3 & 1 & $\begin{array}{l}\text { SOU } \\
\text { TH } \\
\text { AFRI } \\
\text { CA }\end{array}$ & 2 & $\begin{array}{l}0.0 \\
02 \\
73\end{array}$ & 0 & 2 & 1 & $\begin{array}{l}\text { UNIT } \\
\text { ED } \\
\text { KING } \\
\text { DOM }\end{array}$ & 3 & $\begin{array}{l}0.0 \\
022 \\
71\end{array}$ & 0 & 3 & 1 \\
\hline JAPAN & 3 & 0.00135 & 0 & 3 & 1 & $\begin{array}{l}\text { FRA } \\
\text { NCE }\end{array}$ & 1 & $\begin{array}{l}0.0 \\
01 \\
36\end{array}$ & 0 & 1 & 1 & $\begin{array}{l}\text { BRA } \\
\text { ZIL }\end{array}$ & 2 & $\begin{array}{l}0.0 \\
015 \\
14\end{array}$ & 0 & 2 & 1 \\
\hline $\begin{array}{l}\text { MALAYS } \\
\text { IA }\end{array}$ & 3 & 0.00135 & 0 & 3 & 1 & $\begin{array}{l}\text { ITAL } \\
Y\end{array}$ & 1 & $\begin{array}{l}0.0 \\
01 \\
36\end{array}$ & 1 & 0 & 0 & $\begin{array}{l}\text { CHIN } \\
\text { A }\end{array}$ & 2 & $\begin{array}{l}0.0 \\
015 \\
14\end{array}$ & 0 & 2 & 1 \\
\hline $\begin{array}{l}\text { NETHER } \\
\text { LANDS }\end{array}$ & 3 & 0.00135 & 0 & 3 & 1 & $\begin{array}{l}\text { MAL } \\
\text { AYS } \\
\text { IA }\end{array}$ & 1 & $\begin{array}{l}0.0 \\
01 \\
36\end{array}$ & 0 & 1 & 1 & IRAN & 2 & $\begin{array}{l}0.0 \\
015 \\
14\end{array}$ & 0 & 2 & 1 \\
\hline
\end{tabular}

Table 9. Collaborative Countries

Highly Cited Documents

Table 10 highlights the highly cited documents of PSG College of Technology for the study period. Article published in Journal of Manufacturing Technology, 2005 authored by Dr.SR Devadesan has received 21 local citations and 51 global citations. Dr.G Thilagavathy has published a article in Indian Journal of fibre Textile research, 2207 has received 100 global citations.

\begin{tabular}{|c|c|c|c|c|c|}
\hline \multicolumn{6}{|l|}{ PSG College of Technology } \\
\hline Document & DOI & Year & $\begin{array}{l}\text { Local. } \\
\text { Citations }\end{array}$ & $\begin{array}{l}\text { Global. } \\
\text { Citation } \\
\text { s }\end{array}$ & $\begin{array}{l}\text { Local } \\
\text { Citations } \\
(\%)\end{array}$ \\
\hline $\begin{array}{lccc}\text { DEVADASAN } & \text { SR, } & 2005, & \mathrm{~J} \\
\text { MANUF TECHNOL MANAGE } & \\
\end{array}$ & $\begin{array}{l}10.1108 / 17410380510 \\
609456\end{array}$ & 2005 & 21 & 51 & 41.18 \\
\hline $\begin{array}{l}\text { ANANDAKUMAR } \mathrm{H}, 2014, \mathrm{~J} \\
\text { COMPUT SCI }\end{array}$ & $\begin{array}{l}10.3844 / \text { jcssp.2014.74 } \\
5.754\end{array}$ & 2014 & 12 & 31 & 38.71 \\
\hline $\begin{array}{l}\text { PAI GAV, 2009, IEEE TRANS } \\
\text { EVOL COMPUT }\end{array}$ & $\begin{array}{l}\text { 10.1109/TEVC.2009.2 } \\
014360\end{array}$ & 2009 & 10 & 45 & 22.22 \\
\hline $\begin{array}{l}\text { ANANDAKUMAR } \\
\text { CLUSTER COMPUT }\end{array}$ & $\begin{array}{l}10.1007 / \mathrm{s} 10586-017- \\
0798-3\end{array}$ & 2017 & 10 & 100 & 10.00 \\
\hline $\begin{array}{l}\text { THILAGAVATHI } \mathrm{G}, \quad 2007, \\
\text { INDIAN J FIBRE TEXT RES }\end{array}$ & & 2007 & 9 & 70 & 12.86 \\
\hline $\begin{array}{l}\text { RAMESH G, 2007, J MANUF } \\
\text { TECHNOL MANAGE }\end{array}$ & $\begin{array}{l}10.1108 / 17410380710 \\
722890\end{array}$ & 2007 & 9 & 89 & 10.11 \\
\hline $\begin{array}{l}\text { DEVADASAN SR, 2006, TQM } \\
\text { MAG }\end{array}$ & $\begin{array}{l}10.1108 / 09544780610 \\
647865\end{array}$ & 2006 & 9 & 28 & 32.14 \\
\hline
\end{tabular}




\begin{tabular}{|l|l|l|l|l|l|}
\hline $\begin{array}{l}\text { VINODH S, 2008, INT J } \\
\text { PROCESS } \\
\text { BENCHMARKING }\end{array}$ & $\begin{array}{l}\text { MANAGE } \\
10.1504 / \text { IJPMB.2008.0 } \\
17960\end{array}$ & 2008 & 9 & 17 & 52.94 \\
\hline $\begin{array}{l}\text { ANANDAKUMAR H, 2017, } \\
\text { INTELL AUTOM SOFT COMP }\end{array}$ & $\begin{array}{l}10.1080 / 10798587.201 \\
7.1364931\end{array}$ & 2017 & 9 & 59 & 15.25 \\
\hline $\begin{array}{l}\text { VINODH S, 2010, INT J ADV } \\
\text { MANUF TECHNOL-a }\end{array}$ & $\begin{array}{l}10.1007 / \mathrm{s} 00170-009- \\
2142-4\end{array}$ & 2010 & 8 & 34 & 23.53 \\
\hline $\begin{array}{l}\text { ANANDAKUMAR H, 2018, } \\
\text { COMPUT ELECTR ENG }\end{array}$ & $\begin{array}{l}10.1016 / \text { j.compeleceng } \\
.2017 .09 .016\end{array}$ & 2018 & 8 & 101 & 7.92 \\
\hline $\begin{array}{l}\text { DEVADASAN SR, 2003, INT J } \\
\text { QUAL RELIAB MANAGE }\end{array}$ & $\begin{array}{l}10.1108 / 02656710310 \\
476525\end{array}$ & 2003 & 7 & 24 & 29.17 \\
\hline
\end{tabular}

\section{Table 10- PSG College of Technology Highly Cited Documents}

Table 11 highlights the highly cited documents of Coimbatore Institute of Technology for the study period. Article authored by Dr.M Thambidurai (2013) has received 8 local citations and 39 global citations. Dr.N Gokilamani (2013) article has received 53 global citations followed by Dr.S Gopalarishanan has received 96 global citations as shown in the table 11.

\begin{tabular}{|c|c|c|c|c|c|}
\hline \multicolumn{6}{|l|}{ Coimbatore Institute of Technology } \\
\hline Document & DOI & Year & $\begin{array}{l}\text { Local. } \\
\text { Citation } \\
\text { s }\end{array}$ & $\begin{array}{l}\text { Global. } \\
\text { Citations }\end{array}$ & $\begin{array}{l}\text { Local } \\
\text { Citations } \\
(\%)\end{array}$ \\
\hline $\begin{array}{l}\text { THAMBIDURAI M, 2013, MATER } \\
\text { LETT }\end{array}$ & $\begin{array}{l}\text { 10.1016/j.matlet.201 } \\
2.10 .036\end{array}$ & 2013 & 8 & 39 & 20.51 \\
\hline $\begin{array}{l}\text { GOKILAMANI N, 2013, J SOL GEL } \\
\text { SCI TECHNOL }\end{array}$ & $\begin{array}{l}10.1007 / \mathrm{s} 10971-013- \\
2994-9\end{array}$ & 2013 & 7 & 53 & 13.21 \\
\hline $\begin{array}{l}\text { GOPALAKRISHNAN S, 2011, MATER } \\
\text { DES }\end{array}$ & $\begin{array}{l}\text { 10.1016/j.matdes.201 } \\
0.05 .055\end{array}$ & 2011 & 7 & 96 & 7.29 \\
\hline $\begin{array}{l}\text { GOKILAMANI N, 2013, J MATER SCI } \\
\text { MATER ELECTRON }\end{array}$ & $\begin{array}{l}10.1007 / \mathrm{s} 10854-013- \\
1261-8\end{array}$ & 2013 & 6 & 26 & 23.08 \\
\hline $\begin{array}{l}\text { THAMBIDURAI M, 2013, J MATER } \\
\text { SCI MATER ELECTRON-a }\end{array}$ & $\begin{array}{l}10.1007 / \mathrm{s} 10854-013- \\
1103-8\end{array}$ & 2013 & 6 & 16 & 37.50 \\
\hline $\begin{array}{l}\text { THAMBIDURAI M, 2011, J MATER } \\
\text { SCI MATER ELECTRON }\end{array}$ & $\begin{array}{l}10.1007 / \mathrm{s} 10854-011- \\
0342-9\end{array}$ & 2011 & 6 & 29 & 20.69 \\
\hline $\begin{array}{l}\text { SENTHIL TS, 2010, MATER SCI ENG } \\
\text { B SOLID STATE ADV TECHNOL }\end{array}$ & $\begin{array}{l}\text { 10.1016/j.mseb.2010. } \\
04.009\end{array}$ & 2010 & 6 & 44 & 13.64 \\
\hline $\begin{array}{l}\text { KANNAN T, 2006, } \\
\text { PROCESS TECHNOL }\end{array}$ & $\begin{array}{l}\text { 10.1016/j.jmatprotec. } \\
\text { 2006.03.157 }\end{array}$ & 2006 & 6 & 90 & 6.67 \\
\hline $\begin{array}{l}\text { ASHOK KUMAR B, 2012, MATER } \\
\text { DES }\end{array}$ & $\begin{array}{l}\text { 10.1016/j.matdes.201 } \\
2.03 .038\end{array}$ & 2012 & 5 & 105 & 4.76 \\
\hline $\begin{array}{l}\text { SHANMUGA SUNDARAM N, 2010, } \\
\text { MATER DES }\end{array}$ & $\begin{array}{l}\text { 10.1016/j.matdes.201 } \\
0.04 .035\end{array}$ & 2010 & 5 & 88 & 5.68 \\
\hline $\begin{array}{l}\text { KAVITHAMANI A, 2009, IEEE REG } \\
10 \text { ANNU INT CONF PROC TENCON }\end{array}$ & $\begin{array}{l}\text { 10.1109/TENCON.2 } \\
009.5396219\end{array}$ & 2009 & 5 & 11 & 45.45 \\
\hline $\begin{array}{l}\text { RAMAKRISHNAN VM, 2018, MATER } \\
\text { RES BULL }\end{array}$ & $\begin{array}{l}\text { 10.1016/j.materresbu } \\
11.2017 .09 .017\end{array}$ & 2018 & 4 & 45 & 8.89 \\
\hline
\end{tabular}

Table 11-Coimbatore Institute of Technology- Highly Cited Documents

Table 12 reports the highly cited documents published by of Thiagaraja College of Engineering, Madurai for the study period. Article authored by Dr.A Ravi (2011) has received 12 local citations and 76 global citations. Dr.V Velmurugan (2008) article has received 226 global citations.

\begin{tabular}{|l|l|l|l|l|l|}
\hline Thiagaraja College of Engineering & DOI & Year & $\begin{array}{l}\text { Local. } \\
\text { Citations }\end{array}$ & $\begin{array}{l}\text { Global. } \\
\text { Citations }\end{array}$ & $\begin{array}{l}\text { Local } \\
\text { Citations } \\
(\%)\end{array}$ \\
\hline Document & D
\end{tabular}




\begin{tabular}{|c|c|c|c|c|c|}
\hline RAVI A, 2011, SOL ENERGY & $\begin{array}{l}\text { 10.1016/j.solener.20 } \\
11.08 .020\end{array}$ & 2011 & 12 & 76 & 15.79 \\
\hline $\begin{array}{l}\text { VELMURUGAN V, 2008, ENERGY } \\
\text { CONVERS MANAGE }\end{array}$ & $\begin{array}{l}\text { 10.1016/j.enconman. } \\
\text { 2008.05.010 }\end{array}$ & 2008 & 12 & 226 & 5.31 \\
\hline VELMURUGAN V, 2008, ENERGY & $\begin{array}{l}\text { 10.1016/j.energy.20 } \\
08.07 .001\end{array}$ & 2008 & 12 & 134 & 8.96 \\
\hline $\begin{array}{l}\text { KANNAN S, 2009, IEEE TRANS } \\
\text { POWER SYST }\end{array}$ & $\begin{array}{l}\text { 10.1109/TPWRS.20 } \\
08.2004737\end{array}$ & 2009 & 11 & 132 & 8.33 \\
\hline $\begin{array}{l}\text { SARAVANAN M, 2007, ELECTR } \\
\text { POWER SYST RES }\end{array}$ & $\begin{array}{l}10.1016 / \text { j.epsr.2006. } \\
03.006\end{array}$ & 2007 & 11 & 283 & 3.89 \\
\hline $\begin{array}{l}\text { VENKATESH P, 2003, IEEE } \\
\text { TRANS POWER SYST }\end{array}$ & $\begin{array}{l}\text { 10.1109/TPWRS.20 } \\
03.811008\end{array}$ & 2003 & 9 & 314 & 2.87 \\
\hline $\begin{array}{l}\text { MURUGAVEL KK, 2010, APPL } \\
\text { ENERGY }\end{array}$ & $\begin{array}{l}\text { 10.1016/j.apenergy. } 2 \\
009.07 .023\end{array}$ & 2010 & 8 & 176 & 4.55 \\
\hline $\begin{array}{l}\text { KALIDASA MURUGAVEL K, } \\
\text { 2008, DESALINATION-a }\end{array}$ & $\begin{array}{l}10.1016 / \mathrm{j} . \text { desal.2007 } \\
.01 .062\end{array}$ & 2008 & 8 & 118 & 6.78 \\
\hline $\begin{array}{lll}\text { VELMURUGAN } & \text { V, } & 2007, \\
\text { DESALINATION } & & \end{array}$ & $\begin{array}{l}10.1016 / \mathrm{j} . \text { desal.2006 } \\
.12 .012\end{array}$ & 2007 & 7 & 114 & 6.14 \\
\hline $\begin{array}{l}\text { BANUMATHI A, 2007, J MED } \\
\text { SYST }\end{array}$ & $\begin{array}{l}10.1007 / \mathrm{s} 10916- \\
007-9057-0\end{array}$ & 2007 & 7 & 15 & 46.67 \\
\hline $\begin{array}{l}\text { KANNAN S, 2005, IEEE TRANS } \\
\text { POWER SYST }\end{array}$ & $\begin{array}{l}\text { 10.1109/TPWRS.20 } \\
04.840451\end{array}$ & 2005 & 7 & 189 & 3.70 \\
\hline $\begin{array}{l}\text { KANNAN S, 2004, } \\
\text { ELECTR } \\
\text { POWER SYST RES }\end{array}$ & $\begin{array}{l}10.1016 / \text { j.epsr.2003. } \\
12.009\end{array}$ & 2004 & 7 & 194 & 3.61 \\
\hline
\end{tabular}

Table 12-Thiagarajar College of Engineering- Highly Cited Documents

\section{Findings and Suggestions}

- PSG College of Technology, Coimbatore has the highest research productivity compared to Coimbatore Institute of Technology and Thiagarajar College of Engineering, Madurai. The growth of publication is in exponential pattern for the 20 years of period.

- Many of the articles are published as multi authored documents by all the government aided technical higher education institutions in Tamilnadu.

- Dr.S R Devadasan from PSG College of Technology, Dr.N Muthukumarasamy from Coimbatore Institute of technology and Dr.S Baskar are the most prolificauthors of the analyzed institution with highest publications and citations for the study period.

- Journals are the predominant source of publication by all the institutions where as International Journal of Applied Engineering Research is the journal having the highest number of publications by all the institutions.

- PSG College of Technology has collaborated with Coimbatore Institute of Technology for the publications in various journals. These 3 institutional collaborations with NITs and IIT are to be improved.

- Textile Journals has received global citations more than 100 compared to other journals published by studied institutions.

- Material Science is the one of the subject has good number of publications by the referenced institutions.

- Many of the articles were collaborated with Indian institutions apart from USA, Iran, Korea, Malaysia and so on. 


\section{Conclusion}

This paper highlights the various scientometric dimensions of government aided technical institutions in Tamilnadu. It is a timely study to understand the position of institutions where the improvement need to be done inorder to produce the high quality research dynamics in the engineering domain. Research productivity of various institutions can map the gap of research and curriculum in the global scenario. This kind of research to be encourage by the funding bodies to bridge the applications and theory especially in the engineering stream. Nowadays Government has taken various measures to develop the research quality of the institutions by ranking the institution periodically with various dimensions of educational impact. This paper can provide a good insight on institutional performance and its development scientifically.

\section{References}

[1] Agarwal, A., Durairajannayagam, D., Tatagari, S., Esteves, S.C., Harlev, A., Henkel, R., Roychoudhury, S., Homa, S., ...Bashiri, A. (2016). Bibliometrics: tracking research impact by selecting the appropriate metrics. Asian Journal of Andrology, 18, 296-309. doi: 10.4103/1008682X.171582.

[2] Bid, S. (2016). Indian Institute of Technology, Kharagpur: A Scientometric study of Research Output. SSARSC International Journal of Library Information Network and Knowledge, 1(1), 115 .

[3] Mandhirasalam, M. (2016). Research Output of PSG College of Technology, Coimbatore : A Scientometric Study. SRELS Journal of Information Management, 53(3), 229-235. Retrieved from http://www.informaticsjournals.com/index.php/srels/article/view/6400.

[4] Pradhan, B., \& Ramesh, D. B. (2017). Scientometrics of Engineering Research at Indian Institutes of Technology Madras and Bombay during 2006-2015. DESIDOC Journal of Library \& Information Technology, 37(3), 213-220. https://doi.org/10.14429/djlit.37.3.10967.

[5] Rawls, M.W.(2018). Assessing Research Productivity from an Institutional Effectiveness Perspective: How Universities Inflfluence Faculty Research Productivity. Thesis submitted to Virginia Commonwealth University. Retrieved from https://scholarscompass.vcu.edu/etd/5471.

[6] Wootton, R. (2013). A simple, generalizable method for measuring individual research productivity and its use in the long-term analysis of departmental performance, including betweencountry comparisons. Wootton Health Research Policy and Systems, 11(2), 1-14.

[7] M. Tholkapiyan, A.Mohan, Vijayan.D.S , "A survey of recent studieson chlorophyll variation in Indian coastal waters", IOP Conf. Series: Materials Science and Engineering 993 (2020) 012041, doi:10.1088/1757-899X/993/1/012041. 